\title{
MANAGEMENT OF NARCOTICS RECIDIVIST PRISONERS
}

\author{
Muhammad Adi Putra \\ Politeknik Ilmu Pemasyarakatan, Indonesia \\ adiputra300597@gmail.com
}

\begin{abstract}
Repetition of criminal acts or recidivists is a familiar phenomenon in Indonesia, especially acts of narcotics user recidivate, many factors cause a person to repeat his crime, such as economic interests, limited employment, low levels of education is a common problem someone takes a shortcut to get economic success. Correctional Institutions are expected to be able to become a place to return prisoners to become members of the community that are useful for themselves family and also the community but the reality is not as expected. The problem that will be discussed in the writing of this journal is to analyze the factors and how to deal with narcotics addicts so that they do not repeat their actions. Writing this journal uses qualitative methods and data obtained from Literature studies and Document studies. Based on the results of the Analysis of Literature studies and Document studies as well as previous research and discussion by the author emphasizes that the criminal process is said to fail when others commit the same and recurring crimes, and the factors that influence a person to become a narcotics addict to become recidivism are internal and external factors.
\end{abstract}

Keywords: Recidivists, Narcotics Abuse, Rehabilitation

\section{INTRODUCTION}

The rise of narcotics abuse in the community, both among the grassroots and the elite, this has become a discussion and seized the attention of all people because the level of abuse of Narcotics has reached the phase of concern.

Narcotics that contain addictive substances are a class of drugs if they enter the body will affect the functioning of the brain and can also cause dependence effects. In this case, the Government recalls this concern of narcotics abuse, trying to save people who abuse Narcotics by making rules to deal with the crime of drug abuse, by applying Law Number 22 of 1997 on Narcotics, which gives consequences to everyone who abuses Narcotics. can undergo imprisonment, if they meet the demands of the article contained in the law.

Narcotics abuse is deviant behavior and very detrimental when someone becomes a Resdivis. Recidivists are considered as one of the cases that have a high level of risk as a cause of the repetition of the crime committed (Yusuf \& Patrisia, 2011). In this case, the concern arises in every community in addressing the nation's successor. In article 85 of Law No.27 of 1997 concerning Narcotics, it states that anyone without rights and is against the law: (1) Using narcotics group, I for themselves shall be sentenced to a maximum of 4 years' imprisonment, (2) Using narcotics class II for himself was sentenced to a maximum imprisonment of two years, (3) Using narcotics group III for oneself, sentenced to a maximum imprisonment of 1 year.

In facing the threat of narcotics abuse, the government issued presidential instruction No. 6 of 2018 about the national action plan for the prevention and eradication of narcotics abuse and distribution (BPK RI, 2018). Below is narcotics case data obtained from the Directorate General of Corrections updated from 33 regional offices spread throughout the Technical Implementation Unit in Indonesia and the following data: 
Tabel 1. Narcotics Case Data

\begin{tabular}{|c|c|c|c|c|}
\hline \multirow[t]{2}{*}{ NO } & \multirow[t]{2}{*}{ KANWIL } & \multicolumn{3}{|c|}{ YEAR } \\
\hline & & 2018 & 2019 & 2020 \\
\hline 1 & Kanwil Aceh & 2,029 & 3,009 & 2,357 \\
\hline 2 & Kanwil Bali & 802 & 1,019 & 838 \\
\hline 3 & Kanwil Bangka Belitung & 742 & 921 & 1,046 \\
\hline 4 & Kanwil Banten & 3211 & 4,344 & 4,525 \\
\hline 5 & Kanwil Bengkulu & 470 & 416 & 578 \\
\hline 6 & Kanwil D.I Yogyakarta & 197 & 220 & 286 \\
\hline 7 & Kanwil DKI Jakarta & 6,403 & 8,719 & 9,405 \\
\hline 8 & Kanwil Gorontalo & 12 & 14 & 0 \\
\hline 9 & Kanwil Jambi & 1,256 & 1,298 & 1,727 \\
\hline 10 & Kanwil Jawa Barat & 7,841 & 7,620 & 7,736 \\
\hline 11 & Kanwil Jawa Tengah & 3,173 & 4,062 & 4,221 \\
\hline 12 & Kanwil Jawa Timur & 4,714 & 5,123 & 6,499 \\
\hline 13 & Kanwil Kalimantan Barat & 782 & 1,608 & 1,841 \\
\hline 14 & Kanwil Kalimantan Selatan & 3,749 & 4,775 & 5,626 \\
\hline 15 & Kanwil Kalimantan Tengah & 750 & 1,345 & 1,351 \\
\hline 16 & Kanwil Kalimantan Timur & 5,673 & 6,685 & 6,536 \\
\hline 17 & Kanwil Kepulauan Riau & 1,819 & 2,024 & 2,595 \\
\hline 18 & Kanwil Lampung & 2,297 & 2,962 & 2,035 \\
\hline 19 & Kanwil Maluku & 41 & 33 & 21 \\
\hline 20 & Kanwil Maluku Utara & 135 & 189 & 212 \\
\hline 21 & Kanwil Nusa Tenggara Barat & 662 & 739 & 1,078 \\
\hline 22 & Kanwil Nusa Tenggara Timur & 34 & 63 & 44 \\
\hline 23 & Kanwil Papua & 338 & 135 & 0 \\
\hline 24 & Kanwil Papua Barat & 204 & 305 & 34 \\
\hline 25 & Kanwil Riau & 3,337 & 4,221 & 3,698 \\
\hline 26 & Kanwil Sulawesi Barat & 184 & 265 & 363 \\
\hline 27 & Kanwil Sulawesi Selatan & 2,009 & 3,408 & 3,215 \\
\hline 28 & Kanwil Sulawesi Tengah & 261 & 593 & 638 \\
\hline 29 & Kanwil Sulawesi Tenggara & 369 & 472 & 373 \\
\hline 30 & Kanwil Sulawesi Utara & 101 & 112 & 148 \\
\hline 31 & Kanwil Sumatera Barat & 959 & 1,136 & 1,443 \\
\hline 32 & Kanwil Sumatera Selatan & 4,301 & 5,070 & 5,349 \\
\hline 33 & Kanwil Sumatera Utara & 11,999 & 11,316 & 15,400 \\
\hline & Total & 70,854 & 84,221 & 91,218 \\
\hline
\end{tabular}

Source: Sistem Database Pemasyarakatan (2020)

The data above shows that in the 3 years vulnerable there was an increase in Narcotics cases in Indonesia, 260,000 Prisoners in Indonesia faced with Narcotics cases. The data above is presented with a percentage of $50.4 \%$ showed the number of Narcotics cases in Indonesia. It is not wrong if the Head of the Rehabilitation Center of BNN Ali Azhar said that the condition of the Indonesian State was in a serious phase of Drugs. According to him, the strategic condition of the Geographical State of Indonesia is also one of the common factors in the circulation of narcotics in the State of Indonesia which is difficult to control.

Data provided by the National Narcotics Agency in 2018 finally revealed that the percentage of narcotics abuse measures in the Indonesian province reached 3.2 percent or equivalent to 2.29 million people. While in 2017, the National Narcotics Agency (BNN) recorded a percentage of Narcotics abuse of 1.77 percent or equivalent to $3,376,115$ people in the age range of 10-59 years. underage. According to the Head of the BNN Lido Rehabilitation Center when he was a guest speaker at the field study 
program the Correctional Polytechnic Youth Organization held at the Auditorium of the BNN Lido Rehabilitation Center Bogor Regency, Wednesday 26 February 2020 he said the condition of the Indonesian state was now in a state of Drugs this was based on findings He revealed data as much as 3.41 million people in Indonesia are narcotics users. This is very worrying for the survival of the Indonesian nation in the future. And for the world, standard World Drugs Reports in 2018 published by the United Nations Office on Drugs and Crime (UNODC) states that as many as 275 million people in the world or $5.6 \%$ of the world's population aged $15-64$ years have consumed drugs (Puslidatin, 2019).

Even this increasing number of narcotics abuse was recorded by the Directorate General of Corrections in the last September 2018, the data shows that The number of convicted Narcotics cases in Indonesia is 111,848 people consisting of dealers or 67,003 people and 44,845 users. The number of Narotika cases is $45.0 \%$ of the total number of detainees or prisoners in Indonesia, amounting to 248,452 people (Anonim, 2018).

Based on the background above, it can be seen how the crime of narcotics abuse can become a recidivist. It can be seen from the description of the available data. The author wants to examine what can cause the abuse of banned drugs to become a civil servant.

\section{METHODS}

The research method in this writing is qualitative with a phenomenological approach. According to Polkinghorne (Creswell, 1998), phenomenological studies describe an experience or phenomenon. Data collection is carried out by means of Literature Study and also using document study data collection methods. The data collected consists of secondary data. Secondary data obtained through the study of literature and official documents and related agencies. Secondary data collection used in this study is the Literature study which includes secondary data collection obtained from the relevant agencies or institutions. According to Nazir (2013) data collection techniques by conducting a study of reviewers of books, literature, notes, and previous reports relating to the problem being studied.

The concept of a Penal Institution that is considered capable of providing guidance for narcotics convicts is expected to return the public narcotics perpetrators and be accepted by the community and live a normal life in the community because they have realized that their mistakes are felt to be ineffective in fostering convicted narcotics cases. above. Where every Narcotics convict case is not all as users, but there are those who become couriers, dealers, and also in each type of narcotics user, the level of needs is different, because there is a level of trial and error, and there is a level of dependency.

So when we think that when each Narcotics case is put together in one place without clustering either according to age, degree of dependency, or criminal, then this can make a person learn more crime than the crime previously committed by someone (Azkadina, 2017). So in this case writing argues that not everyone who is dealing with a Narcotics case must enter the Penitentiary as a whole, but must be with the Rehabilitation program. This rehabilitation program restores the physical, mental, and health conditions of Narcotics users.

In the general provisions of law No.22 of 1997 concerning Narcotics, Rehabilitation is divided into two types, which include: (1) Medical rehabilitation is a series of integrated treatment processes aimed at freeing addicts from narcotics drug addiction. Medical rehabilitation can be done at a hospital designated by the Minister of Health or the Rehabilitation Center; (2) Social 
Rehabilitation is a series of recovery activities carried out integrated physically, mentally and socially so that a narcotics addict can live normally socially in the community, a person who is meant by a narcotics addict is someone who has recovered from dependence on narcotics physically and psychologically. This rehabilitation can be carried out at social rehabilitation institutions that have been recommended by the government.

Below is the Rehabilitation process carried out by the BNN Rehabilitation Center:

\section{Figure 1. The Rehabilitation process}

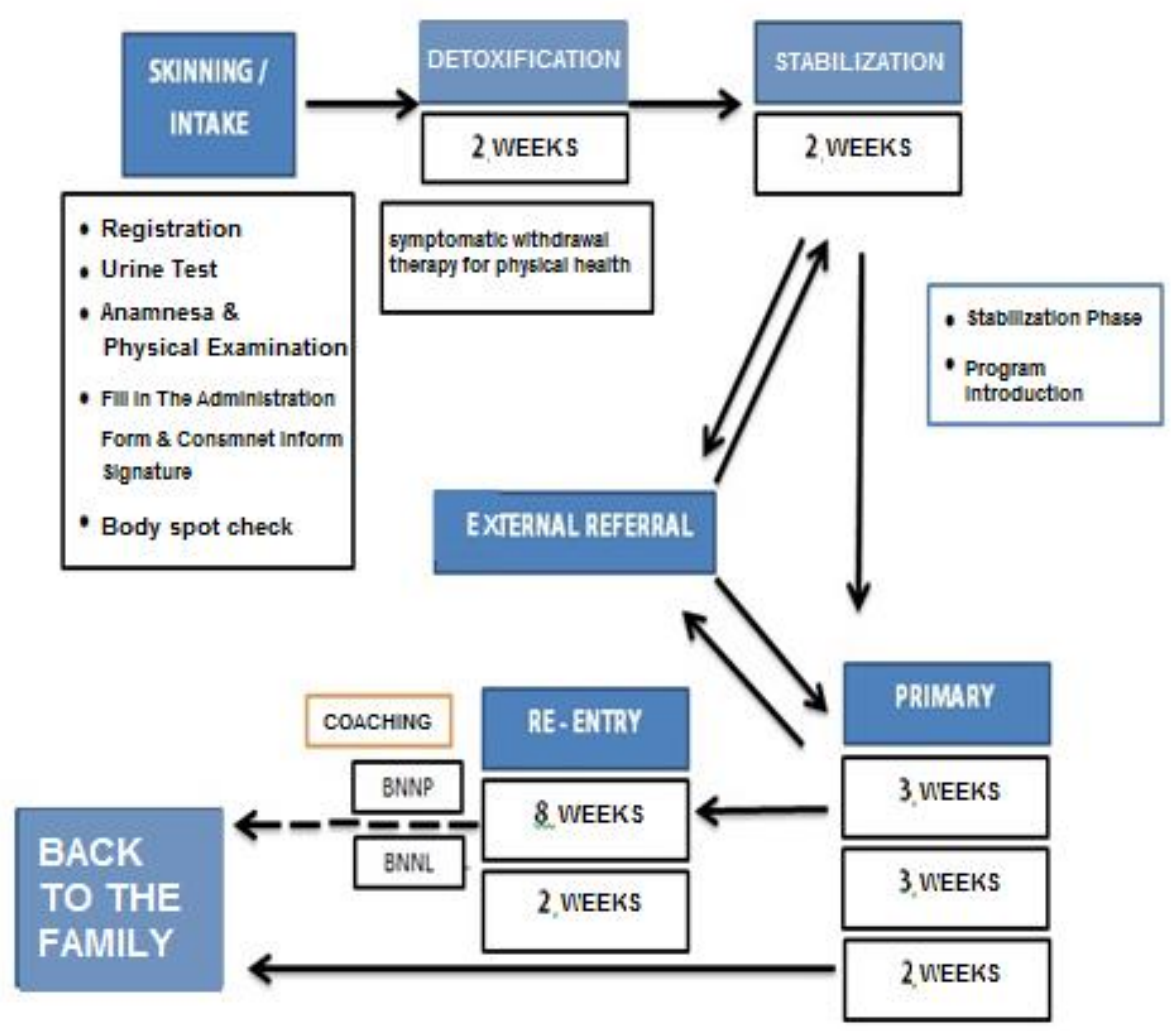

Source: BNN (2019)

From the explanation of the flowchart above, it gives an explanation and reinforcement that every person who experiences narcotics addiction is not enough if only his social rehabilitation is carried out, but must be carried out by medical rehabilitation, because if social and medical rehabilitation is not carried out, then the tendency will change the criminal acts or even commit criminal acts. will increase from the previous case which has the potential to occur, for 8 months a series of Rehabilitation processes will be carried out by the National Narcotics Agency providing guarantees for
Narcotics addicts to be free from Narcotics dependence. like the concept expressed about Recidivism as follows:

Criminal Career: is a criminal offense committed by many people.

Criminal Career: is a person who commits a crime increased from the previous crime.

Criminal career construction in the criminological language is formulated as lambda, it's level (prevalence) and its occurrence (incidence), and initial (onset) and cessation (distance) (Musthofa, 2007). 


\section{RESULTS AND DISCUSSION}

Criminal acts of repatriation or socalled Narcotics abuse recidivists can be carried out by anyone and regardless of the age of the perpetrators. A recidivist is a person who commits a crime and then after undergoing his crime this person commits it again. Even when this person repeats his crime, this person can do more than what he has done. Usually, a convicted convict will be more severe. Recidivists are regulated in articles 486,487 and 488 of the Indonesian Criminal Code (Dwiyatmi, 2006).

Abuse of Narcotics addicts threatened with imprisonment as well as Narcotics addicts who do not report themselves to recover are also threatened with criminal penalties but forced efforts and sentences with rehabilitation, Punishment (Iskandar, 2019). According to Sakidjo \& Purnomo (1990) In the Criminal Code regulations recidivist provisions are the basis for criminal prosecution carried out by someone who commits Narcotics to the extent of this recidivist certainly has a factor that influences someone to commit a criminal offense. In Abdul Syani's theory explain Internal factors and External factors:

Internal factors

Internal factors are factors that arise from one's self or personality. Internal factors of narcotics abuse are biological and psychological factors. Viewed from the aspect of personality, what is meant in terms of personality is the curiosity of someone who encourages doing something, disappointment, impatience from someone, and also anxiety or depression so that they vent and to relieve anxiety for a moment by abusing Narcotics. According to Rosenbaum et al (2009) Depression is an unpleasant emotional state and shallow low mood as a result of the influence of unexpected events, where the manifestations of symptoms can be abrupt at a severe level.
The author believes in terms of depression or anxiety this is something that will certainly be faced by every individual, things like this that encourage each individual to have a way to eliminate feelings of anxiety in him, one of them by abusing Narcotics, when someone tries Narcotics and get a sensation of calm from using Narcotics a person will definitely look back for what can make him calm.

It is true that every human on earth wants to live with a sense of security, calm, and also comfortable, this causes a person to consume Narcotics again because getting things that can make him calm.

\section{Psychological factors}

Psychological factors called Egostrength is a person's ability to deal with depressed conditions, according to Sigmund Freud is described in the ability of individuals to maintain the identity and feelings of themselves in the face of pain, distress, and conflict. According to the author When someone faces unfavorable pressure, someone will look for ways to reduce that pressure, one of the ways is by abusing Narcotics, then when someone finds a way to reduce the pressure they are facing, then this person will repeat it.

\section{External factors}

External factors are motivations or impulses from someone who influences and encourages someone to do something. This influence is what drives a person to abuse narcotics and can cause a person to become a recidivist. Factors of the family, starting from ourselves in the womb until the family has an important role in shaping a person's character when someone does not get love and attention, parents, who are less harmonious, there is no open communication in the family, parents do not provide supervision to children, parents are too spoiled their children, parents are too busy looking for money so forget that in this case, the child will 
be a victim of parents because children are neglected.

According to the author, the family is the smallest group of people but this group has a large influence and role towards someone, a harmonious relationship in the family will create a healthy situation and lead to a good person in someone. In principle, every association in social life will always form norms. We realize whether or not delinquency happens to Narcotics in the education environment is a form of failure of the education system in schools because it is felt that there is a lack of knowledge about the dangers of Narcotics.

According to Baihaqi et al (2005) a component of national resilience is a strong attitude from the people of a country, this tough attitude includes tenacity and strength, the attitude of someone who is a narcotics victim who will be able to survive in very challenging conditions until someone is really declared clean.

This personal resilience will impact on national resilience which is manifested by a sense of harmony between victims of drug abuse and the community, a positive view of 'say no to the drug' will form a country that has a resilient community (Dilliana et al., 2016). According to Arisinta (2013) in the theory of personal resilience developing Resilience is the personal journey of each individual to be able to respond positively to life conditions, each individual has a different perception of life in traumatic events and life events that are full of struggle to face a problem must have a mental endurance that is strong in positive ways rather than by drug abuse.

According to Delamater (2006) Locus of Control is a person's belief to exercise sense control that comes from outside and inside. Many people behave strangely or alienate themselves because they feel unable to control the fate that happens to him. This attitude should be able to be changed by every human being, in this case, humans can determine the destiny they have in other words personal resilience is able to form an attitude to be selected from any existing influence. Develop personal resilience based on Pancasila as a human figure with the implications of being able to have a good character (excellent of character).

The author, in this case, will describe the level of the hierarchy of personal endurance can greatly influence the national defense:

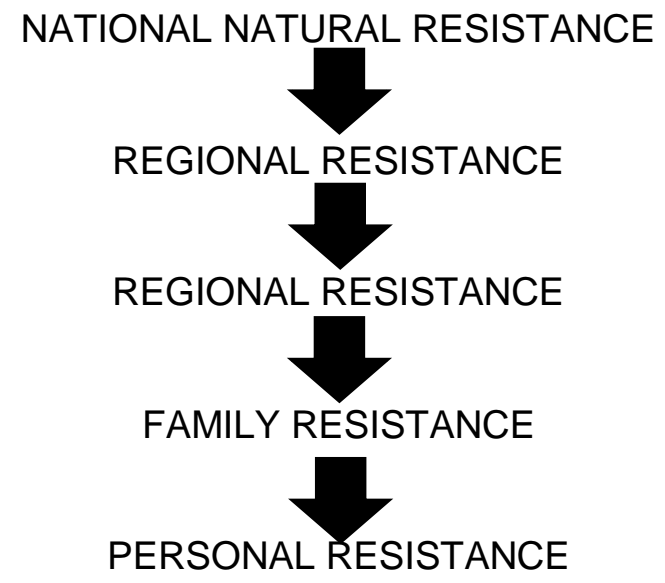

Figure 2. the level of the hierarchy of
personal endurance
Source: Sudarsono (1997)

In this case, the author describes the Personal Resilience of someone who will affect the National Resilience as shown above. According to Baihaqi et al (2005) the component of national resilience is a formidable attitude of a person himself who appears in the community. According to Dilliana et al (2016) so that from such a tough attitude every person in the community can survive to receive pressure. Narcotics abuse and addressing so as not to become a recidivist act abuse of Narcotics. The following below the author will present data on Narcotics abuse cases with a span of 2011-2015: As Head of the National Narcotics Agency (BNN), Heru Winarko revealed data based on the results of a survey conducted in 13 provincial capitals and also, in this case, he worked the same 
as the LIPI Community and Cultural Research Center described at the AntiNarcotics Day commemoration Internasional 06 Juni 2019 then housed in South Jakarta Tribrata Building revealed the results of Narcotics abuse travel rates on students touched $3.21 \%$ equivalent to $2,297,492$ people, and the prevalence among workers reached $2.1 \%$ equivalent to $1,514,037$ people, with the evidence presented BNN revealed in the 2017-2018 timeframe were 48.23 tons of methamphetamine, 41.27 tons of marijuana, 1,594,083 types of ecstasy pills and 2,314.29 kilograms of powder type ecstasy (BNN, 2019). Social factors in criminology are used in schools of cause and effect criminal acts based on social interactions that occur in the community, social processes that occur in the community, and also layers of society that form the social structure that allows criminal acts in the community.

\section{Efforts to tackle Narcotics criminal recidivists}

Narcotics crime in Indonesia becomes very worrying in every element of society, however the commitment so that Indonesia can reduce the level of abuse of Narcotics especially for the nation's successors must be taken seriously and the commitment of every element in the community, because Narcotics can attack anyone not knowing age or whom those who consume it include the children who are the generation of the nation's hopes.

As a society that wants to eradicate Narcotics as an effort to strengthen the country, there must be a preventive effort to reduce the number of criminal acts of narcotics abuse, even to the best Recidivists.

The businesses that can be applied in tackling Narcotics criminal recidivists are as follows:

Preventive action

Action can be carried out by covering the reach of every element of social policy. This preventive effort is carried out with the aim of improving certain social conditions. Efforts to overcome the Narcotics abuse recidivist can be done by starting from the smallest environment first, namely the Family environment, parents can supervise whom our family members associate with. But this can be separated from the role of law enforcement authorities and also the government to provide protection so that people can avoid Narcotics.

This can be done by the government by providing regular counseling to educational institutions and also directly involved in the community about the dangers of drugs.

\section{Repressive measures}

Efforts to overcome acts of narcotics abuse in order to deal with criminal offenses by imposing criminal penalties. The conviction for Narcotics abuse is strictly used.

In addition to the conviction of Narcotics Abuse Recidivists, rehabilitation efforts are also carried out, this is done with the aim of restoring the physical, psychological, mental, moral, and social living conditions of someone who becomes a Narcotics abuse Recidivist. The above was done to avoid the repetition of narcotics abuse. Then prevention efforts through religious guidance to realize that what he did was wrong.

Aspects of law enforcement by means of cooperation between agencies in order to improve operations and also investigate narcotics with cooperation between the National Narcotics Agency and the National Police.

Then in the context of seriously addressing the misuse of narcotics, the National Narcotics Agency (BNN) has drawn up an understanding with the TNI and POLRI that includes commitments in combating Narcotics, namely: (1) The aspects of treatment and rehabilitation in this aspect of government functions are needed to reach a wide range of Narcotics addicts so that Narcotics addicts who do not have access to 
rehabilitation can be immediately dealt with. When someone undergoing rehab should be reported to be required to control and avoid repetition of abusing Narcotics, as written in the regulation of the minister of health Number.80 of 2014. (2) Law and cooperation, in order to support efforts to eradicate Narcotics in cooperation, is a fairly effective way, including cooperation with Interpol, the Ministry of Foreign Affairs both regionally and internationally. This needs to be done to prevent threats from both domestic and domestic. As revealed in the United Nations Office on Drugs and Crime (UNDOC) in 2015 Indonesia is the largest country targeted by drug trafficking. Of course, it is important to pay attention to increasing domestic and international cooperation. (Armaghani, 2018)

From the explanation of the study above, the author in this case believes that every Narcotics user has all the potential to become recidivists, it is because each Narcotics user is only in the initial trial phase, then due to environmental factors and friends will potentially become Recidivists.

This leads to the Differential Association theory revealed by Edwin Sutherland that behavioral violence is studied in a group, which in this case that behavioral crime is the result of studying the crime, in other words when a drug user only uses because he tries only after being punished then this person can repeat his actions and even become a drug dealer because an act of crime is the result of one's learning (Armstrong \& Matusitz, 2013)

Then it also leads to the Domino theory revealed by Heinrich and Frank $E$ Bird which states that accidents are caused by sequential chains of events such as dominoes and when one domino falls, it will trigger the next accident. (concepts and theories in work accidents according to experts) Like the case of Narcotics Abuse that becomes a Recidivist by repeating his actions will even affect others when we look at the above study about the hierarchy of state resilience that is influenced by the personal endurance of each society when resilience the private community is not strong in resisting the pressure it will have an impact on the resilience of the country. And also, in this case, the authors emphasize that every person who experiences Narcotics cases is not enough just to do social coaching, but must be done both socially and medically Rehabilitation, Correctional Institutions as a forum for fostering convicts should be held Rehabilitation programs such as those conducted by the Central Rehabilitation Center BNN because in the series of BNN programs the Social and Medical Rehab is carried out and each case is not the same as each rehab process, because it is tailored to the needs and is based on Gender Classification, age, and also the level of needs.

\section{CONCLUSION}

Based on a study conducted by the author, in this case, concluded that Narcotics criminal recidivists occur due to the impact of the environment due to the conditions of the scope of residence or play someone is a place where the user or dealer is quite intense and the Narcotics abuse recidivist factor of the family is caused by the lack of control functions of the family towards someone because the family is a small scope in the community where its role is very important in controlling one's behavior because we begin in the womb to die we return to the almighty creator (ALLAH SWT) the family is the one who best understands his family members. Recidivism prevention efforts, according to the authors of the results of the study above, can conclude that what can be done in tackling Narcotics criminal recidivists can carry out medical and social, preventive and repressive rehabilitation efforts.

In this paper, the Penitentiary which carries out the functions of guiding prisoners should conduct a Rehabilitation program in collaboration with the BNN Rehabilitation Center or 
with a government hospital recommended by the Minister of Health. And the Narcotics case is not enough just to do social coaching, but must be done both socially and medically rehabilitation.

\section{REFERENCES}

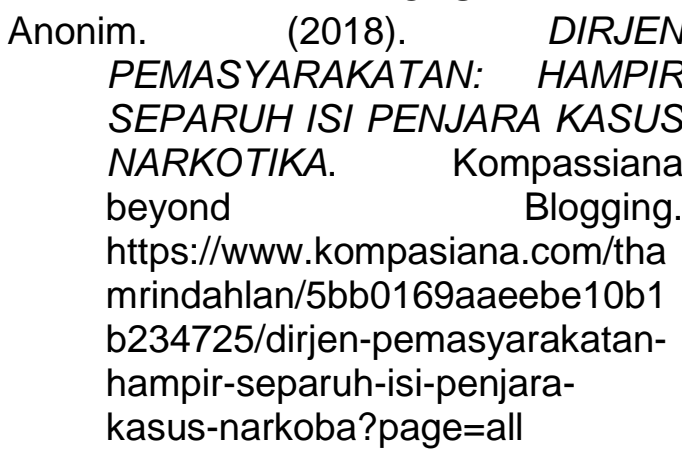

Arisinta, O. (2013). Pengaruh Kompetensi, Independensi, Time Budget Pressure, Dan Audit Fee Terhadap Kualitas Audit Pada Kantor Akuntan Publik Di Surabaya. Jurnal Ekonomi Dan Bisnis Universitas Airlangga, 23(3), 266-278. http://journal.lib.unair.ac.id

Armaghani, H. (2018). Kebijakan Indonesia Pada Era Pemerintahan Presiden Joko Widodo dalam Mewujudkan ASEAN Drug Free Area. Diponegoro University.

Armstrong, T., \& Matusitz, J. (2013). Hezbollah as a Group Phenomenon: Differential Association Theory. Journal of Human Behavior in the Social Environment, 23(4), 475-484.

Azkadina, A. R. (2017). Apa yang dimaksud dengan teori diferensiasi sosial.

Baihaqi, M. I. F., Sunardi, Akhlan, R. N. R., \& Heryati, E. (2005). Buku Psikiatri Konsep Dasar dan Gangguan - gangguan. Refika Aditama.

BNN. (2019). WOW!! HERU WINARKO BEBERKAN FAKTA TERBARU ANGKA PENYALAHGUNAAN NARKOBA. Badan Narkotika Nasional Republik Indonesia. https://bnn.go.id/wow-heruwinarko-beberkan-fakta-terbaru- angka-penyalahgunaan-narkoba/

BPK RI. (2018). Rencana Aksi Nasional Pencegahan dan Pemberantasan Penyalahgunaan dan Peredaran Gelap Narkotika dan Prekursor Narkotika Tahun 2018-2019. JDIH BPK R.I DATABASE PERATURAN.

https://peraturan.bpk.go.id/Home/ Details/89946/inpres-no-6-tahun2018

Delamater, A. (2006). Improving Patient Adherence. Clinical Diabetes, 24(2), 71-77.

Dilliana, R. A., Himam, F., \& Maarif, S. (2016). Peran Konseling Panti Rehabilitasi Dalam Menangani Pemuda Korban Narkoba Dan Implikasinya Terhadap Ketahanan Pribadi (Studi pada Panti Sosial Pamardi Putra, Sleman, Daerah Istimewa Yogyakarta). Jurnal Ketahanan Nasional, 22(3).

Dwiyatmi, S. H. (2006). Pengantar Hukum Indonesi. Ghalia Indonesia.

Iskandar, A. (2019). Penegakan Hukum Narkotika. PT Elex Media Komputindo.

Musthofa, M. (2007). PENELITIAN KARIR KRIMINAL.

Nazir, M. (2013). Metode Penelitian. Ghalia Indonesia.

Puslidatin. (2019). PENGGUNAAN NARKOTIKA DIKALANGAN REMAJA MENINGKAT. Badan Narkotika Nasional Republik Indonesia.

https://bnn.go.id/penggunaannarkotika-kalangan-remajameningkat

Rosenbaum, P., Paneth, N., Leviton, A., Goldstein, M., \& Bax, M. (2009). A report: The definition and classification of cerebral palsy. Developmental Medicine and Child Neurology, 49(109), 8-14.

Sakidjo, A., \& Purnomo, B. (1990). Hukum Pidana Dasar Aturan Umum Hukum. Pidana Kodifikasi. Ghalia Indonesia.

Sistem Database Pemasyarakatan. (2020). Data Kasus Narkoba. 
Almana : Jurnal Manajemen dan Bisnis Vol. 4 No. 2/ Agustus 2020

ISSN 2579-4892 print/ ISSN 2655-8327 online

SDP.

http://smslap.ditjenpas.go.id/publi

c

Sudarsono. (1997). Kamus Konseling.

PT Rineka Cipta.

Yusuf, U., \& Patrisia, R. (2011). PENGARUH TERAPI KOGNITIF

PERILAKU TERHADAP
PENINGKATAN KONTROL DIRI

PADA RESIDIVIS. Jurnal

Intervensi Psikologi, 3(2). 